Małgorzata Broniarek-Machnik, Joanna Kunert, Elżbieta Bołtacz-Rzepkowska

\title{
EVALUATION OF THE PREVENTIVE AND THERAPEUTIC PROGRAMME IMPLEMENTATION 'LET'S TAKE CARE OF A HEALTHY SMILE" AMONG 17- AND 18-YEAR-OLD ADOLESCENTS IN THE CITY OF SKIERNIEWICE IN 2018
}

\author{
OCENA REALIZACJI PROGRAMU PROFILAKTYCZNO-LECZNICZEGO \\ „DBAJMY O ZDROWY UŚMIECH” WŚRÓD 17- I 18-LETNIEJ MŁODZIEŻY \\ W 2018 ROKU W SKIERNIEWICACH
}

Medical University of Łódź, Department of Conservative Dentistry

Zakład Stomatologii Zachowawczej Uniwersytetu Medycznego w Łodzi

\begin{abstract}
The aim of the study was to evaluate the results of the preventive and therapeutic programme addressed to adolescents aged 17 and 18, based on a comparison of the state of dentition prior to and after the completion of the programme.

MATERIAL AND METHODS: All 44 adolescents from the City of Skierniewice and the surrounding area who applied for enrolment were included in the programme. Based on clinical examination, the prevalence of active caries, caries intensity expressed by mean values of the DMFT (decayed, missing, filled teeth) Index including D, M, and F components and the Dental Treatment (DT) Index F/(D + F) were assessed. All parameters were presented according to sex.

RESULTS: Active caries was observed in $34(77.3 \%)$ patients. Caries was more frequently detected in boys $(82.6 \%)$ than in girls (71.4\%). The value of the Caries Intensity Index, DMF, equalled 12.05 and was significantly higher $(p<0.01)$ in boys than in girls: $13.73 \pm 3.63$ and $10.06 \pm 3.42$. In the examined group of 17 - and 18-year-olds, the mean number of decayed teeth $\mathrm{D}(6.31)$ had the highest mean value, followed by the mean number of filled teeth F (4.26), the mean number of extracted (missing) teeth $\mathrm{M}$ (1.48) being the lowest. The values of the F Index were statistically significantly higher $(\mathrm{t}=2.570 ; \mathrm{p}=0.0195)$ in boys as compared to girls $(5.26 \pm$ 2.69 vs. $3.13 \pm 2.83)$. Mean value the Dental Treatment $(\mathrm{DT})$ Index $(\mathrm{F} / \mathrm{D}+\mathrm{F})$ appeared to be higher in the group of boys than in girls: $0.431 \pm 0.182$ and $0.358 \pm 0.126$, respectively. After the completion of the programme, all adolescents studied achieved the value of the Dental Treatment Index equalling 1.

CONCLUSIONS: Dental examination qualifying 17- and 18-year old adolescents in Skierniewice to the preventive and therapeutic programme detected numerous foci of active caries. Implementation of the programme allowed to effectively treat the teeth of the adolescents participating in the project and to develop proper hygiene and dietary habits.
\end{abstract}

Key words: preventive programme,,caries intensity, Dental Treatment Index

\section{STRESZCZENIE}

Celem pracy była ocena wyników programu profilaktyczno-leczniczego, skierowanego do młodzieży w wieku 17 i 18 lat, na podstawie porównania stanu uzębienia przed i po realizacji programu.

MATERIAL I METODY: Do programu przyjęto wszystkich zgłaszających się, czyli 44 nastolatków z miasta Skierniewice i okolic. Na podstawie badania klinicznego oceniono częstość występowania aktywnej próchnicy, intensywność próchnicy wyrażoną za pomocą wskaźnika PUW z uwzględnieniem składowych $\mathrm{P}$, U i W oraz wskaźnik leczenia $\mathrm{W} /(\mathrm{P}+\mathrm{W})$. Wszystkie parametry przedstawiono z uwzględnieniem płci.

WYNIKI: Aktywną próchnicę zaobserwowano u 34 (77,3\%) badanych. Próchnicę częściej stwierdzono u chłopców (82,6\%) niż dziewcząt (71,4\%). Wartość wskaźnika intensywności próchnicy PUW równała się 12,05 i była istotnie wyższa $(\mathrm{p}<0,01)$ u chłopców niż u dziewcząt: odpowiednio $13,73 \pm 3,63$ i 10,06 $\pm 3,42$. W badanej grupie 17 i 18-latków najwyższą średnią wartość przyjęła średnia liczba zębów z próchnicą P - 6,31, następnie średnia liczba zębów wypełnionych W 4,26, najmniejsza była średnia liczba zębów usuniętych U - 1,48. Warto- 
ści wskaźnika $W$ była statystycznie istotnie wyższa $(t=2,570 ; p=0,0195)$ u chłopców niż u dziewcząt $(5,26 \pm 2,69$ vs $3,13 \pm 2,83$ ). Średnia wartość wskaźnika leczenia WL (W/W+P) była wyższa w grupie chłopców niż w grupie dziewcząt. Odpowiednie średnie wynoszą: $0,431 \pm 0,182$ i $0,358 \pm 0,126$. Po zakończeniu programu wszyscy badani osiągnęli wartość wskaźnika leczenia wynoszącą 1.

WNIOSKI: Badania kwalifikujące 17 i 18 -letnią młodzież w Skierniewicach do programu profilaktyczno-leczniczego ujawniły liczne ogniska aktywnej próchnicy. Realizacja programu pozwoliła, na skuteczne leczenie uzębienia osób uczestniczących w projekcie oraz ukształtowanie prawidłowych nawyków higieniczno-dietetycznych.

Slowa kluczowe: program profilaktyczny, intensywność próchnicy, wskaźnik leczenia

\section{INTRODUCTION}

Dental caries is considered to be a civilisation disease (1). Epidemiological data indicates that the state of the child and adolescent dentition in Poland is not satisfactory. The researchers emphasize that there are still great needs for oral health education, dental prevention, and treatment $(2,3,4,5,6)$. Complications induced by untreated caries affect the general health status as well as the development of young patients. Therefore, the monitoring of the oral health status, especially during the developmental age is of great significance.

A growing problem of caries development resulted in establishing the Alliance for a Cavity-Free Future (ACFF) in 2013, which brings together dental practitioners and public health experts. The aim of this organization is to promote and implement public health actions in order to stop caries initiation and growth in patients of all age groups (7). The scope of the "Let's Take Care of a Healthy Smile" programme is consistent with a strategic goal of health policy in the Lódź Province on the improvement of the efficacy of activities related to health promotion and prevention of oral diseases (8).

Due to the scale of the caries problem, The Ministry of Health has implemented a preventive programme called Monitoring of the Oral Health Status among the Polish population in the years 2016-2020. The main goals of the programme are to evaluate the state of oral health and related social, economic, organisational, and cultural determinants (9).

A lack of adequate programmes and insufficient access to preventive services reimbursed from public funds draw the attention of the Supreme Audit Office (NIK in Polish). Its report of 2012 indicated that the involvement of local government units is an indispensable action in the fight against caries. The answer to this directive was the programme developed for the residents of Skierniewice (10).

The city allocated funds in the amount of about 26,000 PLN to finance the designated activities, which allowed to perform restorations of about 200 teeth under local anesthesia. Services of this type in the National Health Fund (NFZ) are provided within the above-standard services and are payable.

\section{WSTĘP}

Próchnica zębów jest chorobą uznawaną za chorobę cywilizacyjną (1). Dane epidemiologiczne wskazują, że stan uzębienia dzieci i młodzieży w Polsce jest niezadowalający. Autorzy badań zwracają uwagę, że nadal istnieją duże potrzeby w zakresie edukacji zdrowotnej, profilaktyki stomatologicznej i leczenia (2-6). Powikłania nieleczonej próchnicy wpływają na ogólny stan zdrowia oraz rozwój młodocianych pacjentów. $Z$ tego powodu monitorowanie stanu zdrowia jamy ustnej, szczególnie w wieku rozwojowym jest bardzo ważne.

Narastający problem próchnicy spowodował, że w 2013 roku zainaugurował działanie Europejski Oddział Sojuszu na Rzecz Przyszłości Wolnej od Próchnicy (ACFF - Alliance for a Cavity-Free Future), który zrzesza lekarzy i ekspertów zdrowia publicznego. Zadaniem stowarzyszenia jest proponowanie i wdrażanie zmian $\mathrm{w}$ procesie przeciwdziałania rozwojowi próchnicy u pacjentów we wszystkich grupach wiekowych (7). Zakres programu jest zgodny ze strategicznym celem polityki zdrowotnej w woj. łódzkim mówiącym o poprawie skuteczności działań dotyczących promocji zdrowia i profilaktyki chorób jamy ustnej (8).

W związku ze skalą problemu Ministerstwo Zdrowia realizuje obecnie program profilaktyczny pod nazwą Monitorowanie Stanu Zdrowia Jamy Ustnej populacji polskiej w latach 2016-2020. Główne cele programu zakładają ocenę stanu zdrowia jamy ustnej, uwarunkowań społecznych, ekonomicznych, organizacyjnych i kulturowych wpływających na ten stan (9).

Brak odpowiednich programów oraz niewystarczający dostęp do profilaktycznych świadczeń refundowanych ze środków publicznych zwrócił uwagę Najwyższej Izby Kontrolnej (NIK). W raporcie z 2012 wykazano, że w walce $\mathrm{z}$ próchnicą nieodzownym działaniem jest zaangażowanie m.in. jednostek samorządów terytorialnych. Odpowiedzią na wytyczne był program opracowany dla mieszkańców Skierniewic (10).

Miasto na sfinansowanie wyznaczonych działań przeznaczyło rocznie środki w wysokości około 26 tys. zł., co pozwalało na wykonanie pacjentów wypełnień w miejscowym znieczuleniu około 200 zębów. Usługi tego typu w NFZ są wykonywane w ramach świadczeń ponadstandardowych i są płatne. 
The aim of the study was to evaluate the results of the preventive and therapeutic programme addressed to adolescents aged 17 and 18, based on a comparison of the state of dentition prior to and after the completion of the programme.

\section{MATERIALS AND METHODS}

The programme was carried out in a few stages and was accomplished in 2018.

All who applied for enrolment were examined. After planning the treatment and obtaining the approval of the Agency for Health Technology Assessment and Tariff System as well as the Governor of Lodz Province, the City Council of Skierniewice presented the programme. The health-care entity, which fulfilled all requirements, was selected through the competition.

Invitations for participation in the programme were addressed to adolescents and their parents. The information about the programme was disseminated in the form of leaflets, posters, and messages on the website of the health-care entity and the City Hall of Skierniewice. Teachers were also involved in the action, presenting the principles of the programme and encouraging adolescents to participate actively in the project.

All 44 adolescents from the City of Skierniewice and the surrounding area who applied for enrolment were included in the programme. Dental visits of $17-$ and 18-year-old patients took place in the dental office of the Medical Centre "Ogrodowa" in Skierniewice. The dental examination, health education activities, qualification for conservative treatment of teeth and treatment procedures were performed by experienced dental practitioners. On the basis of the clinical examination, a treatment plan was prepared and the programme participants as well as their parents or legal guardians got acquainted with it.

Parents and adolescents were requested to consider adhering to an appropriate diet, maintain proper oral hygiene, and pay attention to the essence of the preventive and therapeutic measures. The treatment consisting in the restoration of carious cavities with composite material was adjusted to the individual needs of patients. All adolescents participating in the programme underwent the oral sanation - all carious cavities diagnosed during the clinical examination were restored.

Based on clinical examination, the prevalence of active caries, caries intensity expressed by mean values of the DMFT (decayed, missing, filled teeth) Index including $\mathrm{D}, \mathrm{M}$, and $\mathrm{F}$ components and the Dental Treatment (DT) Index F/(D + F) were assessed. All parameters were presented according to sex.
Celem pracy była ocena wyników programu profilaktyczno-leczniczego, skierowanego do młodzieży w wieku 17 i 18 lat, na podstawie porównania stanu uzębienia przed i po realizacji programu.

\section{MATERIAŁ I METODY}

Program był przeprowadzony w kilku etapach i realizowany w 2018 roku. Badaniu poddano wszystkich zgłaszających się pacjentów.

Po opracowaniu planu działania i zaopiniowaniu przez Agencję Oceny Technologii Medycznych i Taryfikacji oraz Wojewodę Łódzkiego, Rada Miasta Skierniewice przedstawiła program. Podmiot leczniczy, który spełniał wymagania wyłoniono w drodze konkursu.

Zaproszenia do udziału w programie skierowano do młodzieży oraz rodziców. Informacje rozpowszechniono $\mathrm{w}$ formie ulotek plakatów i komunikatów na stronie internetowej podmiotu leczniczego i Urzędu Miasta Skierniewice. W akcję zostali włączeni także nauczyciele, którzy przedstawiali zasady działania programu oraz zachęcali do aktywnego uczestnictwa.

Do programu przyjęto wszystkich zgłaszających się czyli 44 nastolatków z miasta Skierniewice i okolic. Wizyty pacjentów w wieku 17 i 18 lat odbywały się w gabinecie stomatologicznym Centrum Medycznego Ogrodowa w Skierniewicach. Badanie, edukację zdrowotną, kwalifikację do leczenia zachowawczego zębów oraz procedury lecznicze wykonywali doświadczeni lekarze stomatolodzy. W oparciu o badanie kliniczne przygotowano plan leczenia, z którym zapoznano uczestników programu oraz ich rodziców lub opiekunów prawnych. Opiekunom i młodzieży zwrócono uwagę na celowość przestrzegania prawidłowej diety, utrzymania odpowiedniej higieny jamy ustnej oraz istotę podjętego działania profilaktyczno - leczniczego. Leczenie, polegające na wypełnianiu ubytków próchnicowych materiałem kompozytowym dostosowano do indywidualnych potrzeb pacjentów. U wszystkich nastolatków biorących udział w badaniu wykonano sanację jamy ustnej - wypełniono wszystkie zdiagnozowane podczas badania klinicznego ubytki próchnicowe.

Na podstawie badania klinicznego oceniono częstość występowania aktywnej próchnicy, intensywność próchnicy wyrażoną za pomocą wskaźnika PUW z uwzględnieniem składowych P, U i W oraz wskaźnik leczenia $\mathrm{WL}=\mathrm{W} /(\mathrm{P}+\mathrm{W})$. Wszystkie parametry przedstawiono $\mathrm{z}$ uwzględnieniem płci.

Uzyskane wyniki poddano analizie statystycznej. Dla porównania rozkładu występowania aktywnych ognisk próchnicy oraz poszczególnych klas ubytków wg Blacka w zależności od płci zastosowano test niezależności chi-kwadrat. Porównując średnie wartości PUW oraz wskaźniki leczenia, skorzystano z testu tStudenta. Przyjęto poziom istotności $p \leq 0,05$. 
The obtained results were subject to statistical analysis. To compare the distribution of the prevalence of active caries foci and individual carious cavities according to Black's classification and sex, the chisquare independence test was used. The Student's t-test was applied for the comparison of the mean values of the DMFT Index and Dental Treatment Index. The level of significance of $\mathrm{p} \leq 0.05$ was adopted.

\section{WYNIKI}

Grupa biorąca udział w programie liczyła 44 osoby - 21 dziewcząt i 23 chłopców. Aktywną próchnicę zaobserwowano u 34 (77,3\%) badanych. Próchnicę częściej stwierdzono u chłopców $(82,6 \%)$ niż dziewcząt (71,4\%). U 10 osób (22,7\%) nie stwierdzono aktywnych ognisk próchnicy (Tab. I).

Table I. Distribution of active caries cavities in 17- and 18-year-old adolescents by sex.

Tabela I. Rozkład aktywnej próchnicy u 17 i 18- latków w zależności od płci.

\begin{tabular}{|c|c|c|c|c|c|c|c|}
\hline \multicolumn{2}{|c|}{ Variables } & \multicolumn{2}{|c|}{ Active caries } & \multicolumn{2}{|c|}{ Lack of active caries } & \multirow{2}{*}{$\frac{\text { Total }}{\mathrm{N}}$} & \multirow{2}{*}{ Chi-square test } \\
\hline & & $\mathrm{N}$ & $\%$ & $\mathrm{n}$ & $\%$ & & \\
\hline \multirow{3}{*}{ Sex } & Girls & 15 & 71.4 & 6 & 28.6 & 21 & \multirow{3}{*}{$\mathrm{chi}^{2}=0.274 ; p=0.601$} \\
\hline & Boys & 19 & 82.6 & 4 & 17.4 & 23 & \\
\hline & Total & 34 & 77.3 & 10 & 22.7 & 44 & \\
\hline
\end{tabular}

Table II. Mean values of the DMFTM Index and D, M, F components in 17- and 18-year-old adolescents by sex. Tabela II. Średnie wartości PUW oraz P, U i W u 17 i 18-latków w zależności od płci .

\begin{tabular}{|c|c|c|c|c|c|c|c|}
\hline Variables & Sex & D & M & F & DMFT & SD & Student's t- test \\
\hline \multirow{3}{*}{ Sex } & Girls & 5.60 & 1.33 & 3.13 & 10.06 & 3.42 & \multirow{2}{*}{$\mathbf{t}=\mathbf{3 . 3 6 4 ;} \mathbf{p = 0 . 0 0 1 7}$} \\
\cline { 2 - 8 } & Boys & 6.90 & 1.57 & 5.26 & 13.73 & 3.63 & \multirow{2}{*}{} \\
\cline { 2 - 8 } & Total & 6.31 & 1.48 & 4.26 & 12.05 & 3.59 & \\
\hline
\end{tabular}

\section{RESULTS}

The group of subjects participating in the programme included 44 adolescents - 21 girls and 23 boys. Active caries was observed in $34(77.3 \%)$ patients. Caries was more frequently detected in boys $(82.6 \%)$ than in girls (71.4\%). In 10 individuals, no active caries lesions were found (Tab. I).

The value of the Caries Intensity Index, DMFT, equalled 12.05 and was significantly higher $(\mathrm{p}<0.01)$ in boys than in girls: $13.73 \pm 3.63$ and $10.06 \pm 3.42$, respectively (Table 2). In the examined group of 17and 18-year-olds, the mean number of decayed teeth D (6.31) had the highest mean value, followed by the mean number of filled teeth $F$ (4.26), the mean number of extracted (missing) teeth $\mathrm{M}(1.48)$ being the lowest. The values of the F Index were statistically significantly higher $(\mathrm{t}=2.570 ; \mathrm{p}=0.0195)$ in boys as compared to girls $(5.26 \pm 2.69$ vs. $3.13 \pm 2.83)$.

As results from the data presented in Table III, Class II cavities according to Black $(60.6 \%)$ were most frequently observed among the group studied, followed by Class I cavities $(27.8 \%)$, more rarely by Class III $(6.5 \%)$ and Class IV (3.2\%), and most rarely by Class V $(1.8 \%)$. The prevalence of particular classes of cavities in girls and boys did not differ significantly ( $p>0.05$ ). It is worth noticing that Class II, IV, and V cavities were more frequently found in the group of girls, and Class I and III among boys.
Wartość wskaźnika intensywności próchnicy PUW równała się 12,05 i była istotnie wyższa $(p<0,01)$ u chłopców niż u dziewcząt: odpowiednio $13,73 \pm 3,63$ i 10,06 $\pm 3,42$ (Tab. II). W badanej grupie 17 i 18-latków najwyższą średnią wartość przyjęła średnia liczba zębów z próchnicą $P$ - 6,31, następnie średnia liczba zębów wypełnionych W 4,26, najmniejsza była średnia liczba zębów usuniętych $\mathrm{U}$ - 1,48. Wartości wskaźnika W była statystycznie istotnie wyższa $(\mathrm{t}=2,570 ; \mathrm{p}=0,0195) \mathrm{u}$ chłopców niż u dziewcząt $(5,26 \pm 2,69$ vs 3,13 $\pm 2,83)$.

Jak wynika $\mathrm{z}$ danych przedstawionych w tabeli III u badanych najczęściej obserwowano ubytki klasy II wg Blacka (60,6\%), w następnej kolejności klasy I $(27,8 \%)$, znacznie rzadziej ubytki klasy III $(6,5 \%)$ i klasy IV (3,2\%), a najrzadziej klasy V $(1,8 \%)$. Częstość występowania poszczególnych klas ubytków u dziewcząt i chłopców nie różniła się istotnie $(\mathrm{p}>0,05)$. Warto zauważyć, że $\mathrm{w}$ grupie dziewcząt częściej występowały ubytki klasy II, IV i V, a w grupie chłopców klasy I i III. U wszystkich uczestników badania wykonano ogółem 216 wypełnień ze światłoutwardzalnych materiałów kompozytowych w tym: 131 klasy II (79 u chłopców i 52 u dziewcząt, 60 wypełnień klasy I (39 u chłopców i 21 u dziewcząt), 21 wypełnień obejmujących kl III i kl IV (13 u chłopców i 8 u dziewcząt) oraz 4 wypełnienia kl V (3 u dziewcząt i 1 u chłopca). 
Table III. Distribution of caries cavities according to Black's classification in 17- and 18-year-old adolescents by sex. Tabela III. Rozkład ubytków wg klasyfikacji Black’a u badanych 17 i 18-latków w zależności od płci .

\begin{tabular}{|c|c|c|c|c|c|c|c|c|c|c|c|c|}
\hline \multirow{3}{*}{ Sex } & \multicolumn{10}{|c|}{ Black's classes of caries cavities } & \multirow{2}{*}{\multicolumn{2}{|c|}{ Total }} \\
\hline & \multicolumn{2}{|c|}{ Class I } & \multicolumn{2}{|c|}{ Class II } & \multicolumn{2}{|c|}{ Class III } & \multicolumn{2}{|c|}{ Class IV } & \multicolumn{2}{|c|}{ Class V } & & \\
\hline & $\mathrm{n}$ & $\%$ & $\mathrm{~N}$ & $\%$ & $\mathrm{n}$ & $\%$ & $\mathrm{n}$ & $\%$ & $\mathrm{n}$ & $\%$ & $\mathrm{n}$ & $\%$ \\
\hline Girls & 21 & 25.0 & 52 & 61.9 & 4 & 4.8 & 4 & 4.8 & 3 & 3.6 & 84 & 100 \\
\hline Boys & 39 & 29.5 & 79 & 59.8 & 10 & 7.6 & 3 & 2.3 & 1 & 0.8 & 132 & 100 \\
\hline Total & 60 & 27.8 & 131 & 60.6 & 14 & 6.5 & 7 & 3.2 & 4 & 1.8 & 216 & 100 \\
\hline
\end{tabular}

$\mathrm{chi}^{2}=1.816 ; \mathrm{p}=0.770$

Table IV. Dental Treatment (DT) Index values among 17- and 18-year-old adolescents (prior to the beginning and after the completion of the programme).

Tabela IV. Wskaźniki leczenia wśród 17 i 18-latków ( przed rozpoczęciem i po zakończeniu programu).

\begin{tabular}{|c|c|c|c|c|c|}
\hline \multirow{2}{*}{ Variables } & Sex & $\begin{array}{c}\text { DT Index prior } \\
\text { to the programme }\end{array}$ & SD & Student's t- Test & $\begin{array}{c}\text { DT Index after } \\
\text { the programme }\end{array}$ \\
\hline \multirow{3}{*}{ Sex } & Girls & 0.358 & 0.126 & \multirow{2}{*}{$\mathrm{t}=1.498 ; \mathrm{p}=0.142$} & $1.0 \pm 0.0$ \\
\cline { 2 - 4 } & Boys & 0.431 & 0.182 & & $1.0 \pm 0.0$ \\
\cline { 2 - 5 } & Total & 0.403 & 0.161 & $\mathrm{X}$ & $1.0 \pm 0.0$ \\
\hline
\end{tabular}

In all study participants, a total of 216 cavities were restored using light-cured resin composite materials including 131 Class II cavities ( 79 in boys and 52 in girls), 60 Class I cavities (39 in boys and 21 in girls), and 21 cavities of Class III and IV (13 in boys and 8 in girls) as well as 4 Class $\mathrm{V}$ cavities ( 3 in girls and 1 in a boy).

Analyzing the values of the Dental Treatment(DT) Index (F/D+F), it should be noted that its mean value appeared to be higher in the group of boys than in girls: $0.431 \pm 0.182$ and $0.358 \pm 0.126$, respectively. The statistical analysis did not confirm the statistically significant difference $(p>0.05)$ in the values of this parameter according to sex (Table IV). After the completion of the programme, all adolescents studied achieved the value of the Dental Treatment Index equalling 1 .

\section{DISCUSSION}

Preventive programmes for dental services addressed to children and adults are not implemented in Poland by the National Health Fund. Nevertheless, city councils occasionally plan preventive and therapeutic activities, like those organized in Brzeg Dolny, Ciechocinek, and Wałbrzych, which always meet with a positive social reception and significantly support families, especially those with many children. The scope of the present programme is consistent with the National Health Programme for years 20162020, which recommends undertaking prophylactic measures, i.e. integrated prevention of dental caries, including the organization of free of charge dental care for children and adolescents (11).

Young adults, i.e. 18-year-olds, are, however, beneficiaries of services allocated to adults, which are available in the restricted scope. Conservative treatment, as part of the services guaranteed by the National Health Fund, consists mainly of amalgam, glass-ionomer and
Analizując wartości wskaźnika leczenia WL (W/ $\mathrm{W}+\mathrm{P})$ należy zauważyć, że średnia wartość okazała się wyższa w grupie chłopców niż w grupie dziewcząt. Odpowiednie średnie wynoszą: $0,431 \pm 0,182$ i 0,358 $\pm 0,126$. Analiza statystyczna nie potwierdziła różnicy istotnej statystycznie $(p>0,05) \mathrm{w}$ wartościach tego parametru w zależności od płci (tab. IV). Po zakończeniu programu wszyscy badani osiągnęli wartość wskaźnika leczenia wynoszącą 1.

\section{DYSKUSJA}

Programy profilaktyczne w zakresie świadczeń stomatologicznych dla dzieci i osób dorosłych nie są realizowane w Polsce w ramach Narodowego Funduszu Zdrowia. Planowane przez urzędy miast działania profilaktyczno - lecznicze zawsze spotkają się z pozytywnym odbiorem społecznym $\mathrm{i}$ istotnie wspierają rodziny, szczególnie wielodzietne. Podobne programy realizowały samorządy gminy Brzegu Dolnego, Ciechocinka i Wałbrzycha. Zakres programu jest zgodny z Narodowym Programem Zdrowia na lata 2016-2020, który zaleca prowadzenie działań zapobiegawczych tj. zintegrowana profilaktyka próchnicy zębów, w tym organizacja bezpłatnej opieki stomatologicznej dla dzieci i młodzieży (11).

Młodzi dorośli, czyli 18-latkowie, są jednak beneficjentami świadczeń z koszyka przeznaczonego dla osób dorosłych, które są ograniczone. Leczenie zachowawcze, w ramach świadczeń gwarantowanych przez NFZ, to głównie wypełnienia amalgamatowe, glasjonomerowe oraz kompozyty chemoutwardzalne. Szeroka gama materiałów światłoutwardzalnych, oferowanych w sektorze prywatnym, bywa również dostępna $\mathrm{w}$ realizowanych przez jednostki samorządowe programach profilaktyczno-leczniczych. Są one kierowane do różnych grup wiekowych, które mają na 
chemically-cured resin composite restorations. A wide range of light-cured resin materials, offered in the private sector, can be also available in preventive and therapeutic programmes implemented by local authorities. They are addressed to various age groups and are aimed at securing dental treatment needs and services, which are not covered by the National Health Fund.

Older adolescents, 17 and 18 years old, usually have the ability and the right to make their own decisions concerning health. The lack of the necessity to perform control tests in this age group poses a problem which was encountered while recruiting participants to the preventive and therapeutic programme carried out in Skierniewice. Finally, 44 subjects joined this project.

Based on epidemiological studies conducted in 20102018 in various age groups by different authors $(4,5,6$, $12.12 \mathrm{a}$ ), a high incidence of caries was found not only in 18-year-old adolescents but also in younger children in Poland. Among patients of this project, the mean DMFT value was 12.05 and was higher than among adolescents from Rzeszów (9.45), Wrocław (6.5), the Lublin Province (9.13) and the Podkarpackie Province $(9.39)(2,3)$.

The dental examination of the programme participants in Skierniewice revealed that the mean value of the DMFT Index was significantly $(p<0.01)$ higher in boys (13.73) as compared to the group of girls (10.06) (Tab. II). The authors of the reports citied above $(6,13,14)$ did not observe such a correlation.

When assessing the components of the DMF Index, large discrepancies have been detected in the values of the mean number of carious teeth presented in various epidemiological studies. Among adolescents in Skierniewice, this value was 6.31 and was distinctly higher than that in Nisko (a small town) (5.51), Rzeszów (a large city) (3.76), or in the Lublin Province (2.80) and Poznań $(1.44)(3,15)$. As it results from the presented data, the needs for the treatment of dental caries in 17- and 18-year-olds from Skierniewice significantly exceed the needs of peers from Poznań and South-Eastern Poland.

Our own results concerning the mean number of teeth extracted (missing) due to caries demonstrated that the $\mathrm{M}$ value was 1.48 and was found to be higher than that achieved in the study in Poznań, where it equalled 0.62 (16). Moreover, the previous examinations performed among 18-year-old adolescents living in the Łódź Province also indicated a definitely lower value of this parameter. Ćwiklak et al. (5), while analysing the impact of health-promoting behaviours on caries intensity in students after completing lower secondary schools in Łódź reported that this value was 0.095 in secondary schools and 0.26 in vocational schools. Hilt et al. (4), in the study conducted in the Lódź Province, also recorded low values of the $\mathrm{M}$ component ranging from 0.08 to 0.62 depending on the place of residence (a big city, small town, village). celu zabezpieczenie potrzeb leczniczych nie refundowanych przez NFZ.

Starsza młodzież, 17- i 18- letnia, w większości posiada zdolność i prawo do samodzielnego podejmowania decyzji w zakresie zdrowia. Brak konieczności wykonywania badań kontrolnych w tej grupie wiekowej stanowił problem z naborem uczestników do programu profilaktyczno-leczniczego w Skierniewicach. Ostatecznie do programu przystąpiły 44 osoby.

$\mathrm{Na}$ podstawie badań epidemiologicznych prowadzonych w latach 2010-2018 w różnych grupach wiekowych przez różnych autorów $(4,5,6,12,12$ a), stwierdzono dużą zapadalność na próchnicę nie tylko wśród młodzieży 18-letniej lecz również u młodszych dzieci w Polsce. Wśród pacjentów niniejszego projektu średnia wartość PUW wynosiła 12,05 i była wyższa niż wśród młodzieży z Rzeszowa $(9,45)$, Wrocławia $(6,5)$, woj. lubelskiego $(9,13)$ i woj. podkarpackiego $(9,39)(2,3)$.

Badania uczestników programu w Skierniewicach pokazały, że średnia wartość wskaźnika PUW była istotnie $(\mathrm{p}<0,01)$ wyższa u chłopców - 13,73 niż u dziewcząt - 10,06 (tab2.) Autorzy cytowanych wyżej doniesień $(6,13,14)$ nie odnotowali takiej zależności.

Oceniając składowe wskaźnika PUW zaobserwowano duże rozbieżności w wartości średniej liczby zębów z próchnicą przedstawionych $\mathrm{w}$ różnych przeglądach epidemiologicznych. U młodzieży skierniewickiej wskaźnik ten wynosił 6,31 i był wyraźnie wyższy niż w Nisku (małe miasto) - 5,51, Rzeszowie (duże miasto) -3,76, czy w woj. lubelskim - 2,80 oraz Poznaniu -1,44 $(3,15)$. Jak wynika z przedstawionych danych potrzeby w zakresie leczenia próchnicy zębów 17 i 18-latków ze Skierniewic znacząco przewyższały potrzeby rówieśników z Poznania i Polski południowo -wschodniej.

Wyniki własne dotyczące średniej liczby zębów usuniętych z powodu próchnicy, pokazały, że wartość U wyniosła 1,48 i była wyższa od uzyskanych w badaniach w Poznaniu gdzie przyjęła wartość 0,62 (16). Na podstawie wcześniej wykonanych przeglądów wśród 18-latków mieszkających w województwie łódzkim można stwierdzić, że wartość tego parametru była zdecydowanie niższa. Ćwiklak i wsp. (5), analizując wpływ zachowań prozdrowotnych na intensywność próchnicy uczniów szkół ponadgimnazjalnych w Łodzi stwierdzili, że w LO równał się on 0,095 , a w ZSZ 0,26 . Hilt i wsp. (4) po badaniach przeprowadzonych w województwie łódzkim także odnotowała niskie wartości liczby $U$ zawierające się od 0,08 do 0,62 w zależności od miejsca zamieszkania (duże miasto, małe miasto, wieś).

Wartość składowej W u młodzieży uczestniczącej w programie wynosiła średnio 4,26 i była istotnie wyższa u chłopców $(\mathrm{W}=5,26)$ w porównaniu $\mathrm{z}$ dziew- 
The value of the $\mathrm{F}$ component among the adolescents participating in the programme was 4.26 on average and was statistically significantly higher in boys $(\mathrm{F}=5.26)$ as compared to girls $(\mathrm{F}=3.13)$. Hilt et al. indicate that the mean value of the component $\mathrm{F}$ was 5.52 and did not differ by sex (4). In the Podkarpackie Province $(2,3)$, this value equalled $5.51 \pm 3.54$ in a big city and $4.79 \pm 3.91$ in a small town.

In our study, more than half of carious cavities qualified for treatment were Back's Class II $(60.6 \%)$, then Class I (27.8\%) and III cavities (6.5\%), the remaining Class IV and V were reported in isolated cases. Among young people from the Podkarpackie Province, Mielnik-Blaszczak more frequently recorded the need for restoration of cavities on one surface $(1.58 \%$ of subjects in the city and $0.82 \%$ in the village) than on two or more surfaces (1.18\% and $0.43 \%$, respectively) (2).

The fact that only $22.7 \%$ of programme participants did not require any caries treatment is not a positive sign of dental care in Skierniewice. More favourable results were presented in the study by Mielnik-Błaszczak cited above (2.3) in which no carious lesions were found in more than $1 / 3$ of the study population $(36.67 \%)$. Our research showed that among 17- and 18-year-olds, a greater number of girls $(28.6 \%)$ were free from caries compared to boys (17.4\%) (Table 1$)$.

The Dental Treatment (DT) Index reflects the fulfilment of needs for conservative treatment of caries (17). The low value of this index (0.40) among the adolescents in Skierniewice observed before their participation in the programme indicates that less than half of the carious cavities were filled. The analysis of previous values of this index in the Łódź Province revealed that it was systematically improving: and thus, in 1999 it was 0.58 , in $2001-0.66$, in $2004-0.7$ $(18,19)$, and in $2010-0.8$ (4). After the completion of the present programme, the DT Index reached the maximum value of 1 , which indicates that all diagnosed carious defects were filled and the dentition of young adults in Skierniewice improved. The difference in the DT Index value before and after the programme was statistically significant $(\mathrm{t}=24.299 ; \mathrm{p}=0.0000)$.

\section{CONCLUSIONS}

Dental examination qualifying 17- and 18-year old adolescents in Skierniewice to the preventive and therapeutic programme detected numerous foci of active caries. This does show an inadequate dental care as well as unsatisfactory knowledge and health awareness on the importance of prevention and treatment of dental caries among adolescents.

The "Let's take care of a healthy smile" programme was a significant supplement to the existing services guaranteed by the National Health Fund. Its czętami (W=3,13). Badania Hilt i wsp. wskazują, że średnia wartość wskaźnika W wynosiła 5,52 i nie różniła się w zależności od płci (4). W woj. podkarpackim $(2,3)$ wskaźnik kształtował się na poziomie 5,5 $\pm 13,54$ w dużym mieście i 4,79 $\pm 3,91 \mathrm{w}$ małym mieście.

$\mathrm{W}$ naszych badaniach ponad połowę $(60,6 \%) \mathrm{ubyt}$ ków zakwalifikowanych do leczenia stanowily ubytki klasy II, następnie klasy I (27,8\%) i III $(6,5 \%)$, pozostałe klasy IV i V odnotowano w pojedynczych przypadkach. Mielnik-Błaszczak u młodzieży z województwa podkarpackiego częściej stwierdziła potrzebę wypełnienia ubytków na 1 powierzchni $(1,58 \%$ osób w mieście i $0,82 \%$ na wsi) niż na 2 lub więcej powierzchniach (odpowiednio 1,18\% i 0,43\%) (2).

Fakt, że tylko u 22,7\% uczestników programu nie stwierdzono potrzeb w zakresie leczenia próchnicy nie świadczy dobrze o opiece stomatologicznej w Skierniewicach. Korzystniejsze wyniki przedstawiła cytowana wyżej Mielnik-Błaszczak $(2,3)$ gdzie u ponad 1/3 badanej populacji $(36,67 \%)$ nie odnotowano ubytków próchnicowych. Nasze badania pokazały, że w wieku 17 i 18 lat więcej dziewcząt $(28,6 \%)$ było wolnych od próchnicy niż chłopców (17,4\%) (Tab.1).

Wskaźnik leczenia - WL odzwierciedla zaspokojenie potrzeb zachowawczego leczenia próchnicy (17). Niska wartość tego wskaźnika $(0,40)$ u młodzieży skierniewickiej obserwowana przed przystąpieniem do programu wskazuje, że mniej niż połowa ubytków próchnicowych była wypełniona. Analizując wcześniejsze wartości tego wskaźnika w woj. łódzkim można zauważyć, że ulegał on systematycznej poprawie. I tak w 1999 roku wyniósł 0,58, w 2001 - 0,66, w 2004 - 0,7 (18, 19), a w 2010 0,8 (4). Po zakończeniu programu, wskaźnik WL osiągnął maksymalną wartość $=$ 1 , co świadczy o wypełnieniu wszystkich zdiagnozowanych ubytków próchnicowych i tym samym poprawie stanu uzębienia młodocianych dorosłych w Skierniewicach. Różnica w wartości wskaźnika WL przed rozpoczęciem i po zakończeniu programu była istotna statystycznie $(t=24,299 ; p=0,0000)$.

\section{WNIOSKI}

Badania kwalifikujące 17- i 18-letnią młodzież w Skierniewicach do programu profilaktyczno-leczniczego ujawniły liczne ogniska aktywnej próchnicy. Nie świadczy to korzystnie o opiece stomatologicznej, ale też wiedzy i świadomości zdrowotnej w zakresie profilaktyki i leczenia próchnicy zębów wśród nastolatków.

Program „Dbamy o zdrowy uśmiech” był istotnym uzupełnieniem istniejących świadczeń gwarantowanych przez NFZ. Jego realizacja pozwoliła, nie tylko na skuteczne leczenie uzębienia osób uczestniczących w projekcie, ale też na wyrobienie prawidłowych na- 
implementation allowed not only to effectively treat the teeth of the adolescents participating in the project, but also to develop proper hygiene and dietary habits. Positive experiences and the information and educational action are supposed to increase dental care among young adults from Skierniewice. Moreover, It can also be assumed that the experience of 18 -year-olds gained during their participation in the programme will enable them to create proper health-promoting attitudes in their children.

\section{REFERENCES}

1. Szatko F, Wierzbicka M, Grzybowska A. Kariogenne wzorce żywieniowe polskich dzieci narzucane przez sklepiki szkolne. Przegl Stom Wieku Rozw 2001; 3/4: 80-87

2. Mielnik-Błaszczak $M$, i in. Ocena stanu zdrowia jamy ustnej w zakresie próchnicy u młodzieży 18-letniej ze środowiska miejskiego i wiejskiego w województwie podkarpackim, Polska. Przegl Epidemiol 2016; 70: 133-136

3. Mielnik-Błaszczak M, i in. Ocena stanu uzębienia u pacjentów w wieku 15 i 18 lat z regionu Polski południowo-wschodniej ( województwo podkarpackie). Nowa Stomatol 2013; 1: 26-30

4. Hilt A, i wsp.. Tendencje $\mathrm{w}$ zachorowalności na próchnicę zębów u młodzieży 18-letniej z województwa łódzkiego w latach 1995-2008. Przegl Epidemiol 2010; 64: 443-447

5. Ćwiklak K, i wsp.. Analiza zachowań prozdrowotnych młodzieży 18-letniej uczęszczjącej do szkól średnich w Łodzi. Nowa Stomatol 2011; 3: 91-96

6. Królewska-Gawrzyńska J. Stomatologiczne zachowania prozdrowotne a stan uzębienia łódzkiej młodzieży 18-letniej. Nowa Stomatol 2015; 4, 20: 153-158

7. Aliance for a Cavity - Free Future. http://www/ alianceforacavityfreefuture-cee.eu/Caries/Consu$\mathrm{mer} / \mathrm{pl} / \mathrm{pl}$ (dostęp: 25.06.2017)

8. Strategia Polityki Zdrowotnej dla woj. Łódzkiego na lata 2014-2020. Departament Polityki Zdrowotnej Urzędu Marszałkowskiego woj. łódzkiego. Łódź 2014

9. Dane Ministerstwa Zdrowia: Monitorowanie stanu zdrowia jamy ustnej populacji polskiej w latach 2016-2020- dokument elektroniczny www.mz.gov.pl

10. Dostępność i finansowanie opieki stomatologicznej ze środków publicznych, informacja o wynikach kontroli NIK. KZD-4101-04/2012, nr ewid.131/2013/ $\mathrm{p} / 12 / 124 / \mathrm{K}$

11. Rozporządzenie Rady Ministrów z dnia 4 sierpnia 2016 r. w sprawie Narodowego Programu Zdrowia na lata 2016-2020 - Dz.U. 2016 poz. 1492

12. Frączak B, Rawski P, Dembowska E. Stan uzębienia, przyzębia oraz występowanie wad zgryzu u poborowych województwa zachodniopomorskiego. Annales Acdemiae Medicae Stetinensis Roczniki Pomorskiej Akademii Medycznej w Szczecinie 2008; 54, 3: 63-68 wyków higieniczno-dietetycznych. Można sądzić, że pozytywne doświadczenia oraz akcja informacyjno-edukacyjna zwiększą dbałość o uzębienie młodych dorosłych ze Skierniewic. Można również przypuszczać, że doświadczenia 18 latków zdobyte w trakcie realizacji programu pozwolą odpowiednio kształtować postawy prozdrowotne,, swoich dzieci.

13. Broniarek Machnik M., Zielińska R., Bołtacz Rzepkowska E.: Ocena stanu uzębienia u dzieci 6 letnich z rejonu Skierniewic. Przegl Epidemiol 2017;71(4):613- 622

14. Wierzbicka M, Szatko F, Rucińska-Szysz K, Zawadziński M. Ogólnokrajowy Monitoring Zdrowia Jamy Ustnej i Jego Uwarunkowań. Polska 2001; Ministerstwo Zdrowia, Warszawa 2001

15. Wierzbicka M, Petersen P, Moller I. Prace nad poprawą zdrowia jamy ustnej i rozwojem opieki stomatologicznej w Polsce. Oczekiwane kierunki rozwoju opieki stomatologicznej w Polsce w świetle prac warsztatów ekspertów ŚOZ z Krajowym Nadzorem Stomatologicznym. Czas Stomatol 1999; 52, 7: 483-493

16. Chłapowska J, Liweń B, Pawlaczak-Kamieńska T, Burchardt D. Choroba próchnicowa u młodzieży szkolnej Poznania objętej i nieobjętej nadzorowanym szczotkowaniem zębów preparatami fluorkowymi. Dent Med Probl 2009; 46, 2: 197-201

17. Lempe B. Kliniczna ocena stanu uzębienia i uzupełnień protetycznych 18-latków oraz ich wiedza o potrzebach leczenia stomatologicznego. Dent Med Probl 2004; 41, 3 :433-440

18. Jańczuk Zbigniew i in. Stomatologia zachowawcza $z$ endodoncją. PZWL, Warszawa 2014; 229-230

19. Hilt A. Ząb pierwszy trzonowy stały- stan i potrzeby lecznicze na podstawie badań epidemiologicznych i klinicznych u dzieci w wieku 7,12, 18 lat; Rozprawa doktorska z Zakładu Stomatologii Dziecięcej Akademii Medycznej w Łodzi, Łódź 2000

20. Rybarczyk i in. Ocena stanu uzębienia młodzieży 18-letniej w woj. łódzkim w roku 2004. Zdr Publ $2005 ; 115,3: 287-290$

Received:8.07.2019

Accepted for publication: 5.11.2019

Otrzymano: 8.07.2019 r.

Zaakceptowano do publikacji: 5.11.2019 r.

Address for correspondence:

Adres do korespondencji:

Dr Małgorzata Broniarek - Machnik, DDS, PhD

Department of Conservative Dentistry,

Medical University of Lodz,

92-213 Łódź, ul. Pomorska 251

tel: (42) 67574 18, e-mail: malgoska01@wp.pl 